\title{
The Problem with ‘Accurate' History: Complexity within Sallust’s Bellum Catilinae
}

\author{
Haoyang $\mathrm{Xu}^{1}$ \\ ${ }^{1}$ Department of History, Junior at Kent High School, United States \\ Correspondence: Haoyang Xu, Department of History, Junior at Kent High School, United States
}

Received: August 3, 2020

Accepted: October 10, 2020

Available online: October 22, 2020

doi:10.11114/ijsss.v8i6.4952

URL: https://doi.org/10.11114/ijsss.v8i6.4952

\begin{abstract}
Sallust's Bellum Catilinae has long interested historians as one of the few primary accounts of Catiline's conspiracy and for its complicated portrayal of its protagonist. Rather than depicting Catiline's conspiracy as either a villainous rebellion or a courageous attempt at revolution, Sallust allows Catiline and his contemporaries to be complex, sometimes contradictory characters in complicated circumstances. In this paper, I begin by suggesting how Sallust nuances Catiline's character by making him a symptom of widespread decline in the late Roman Republic. I then consider how Sallust's inclusion of four speeches by Catiline, Caesar, and Cato helps him depict history as complicated by allowing his historical figures to represent their viewpoints in their own persuasive voices. I conclude that Sallust draws attention to the complexity of history in his analysis of Catiline, in order to help his contemporary readers realize the danger that the Republic was facing.
\end{abstract}

Keywords: Sallust, Catiline, Roman Republic, Polyphony, Bellum Catilinae, complexity, classical culture, Latin, complexity, rhetoric, Roman literature

\section{Introduction}

Sallust's Bellum Catilinae is an account of Catiline's conspiracy, but it is also a reflection on how history should be told. The great orator Cicero indicates in his De Oratore that a historian 'must not dare to tell any falsehood, and the next, he must be bold enough to tell the whole truth' (Cicero, 2.62). In keeping with Cicero's notion of history that tells the "whole truth," contemporary historians of classical antiquity have debated how to most accurately characterize the late period of the Roman Republic. According to Sallust and many of his contemporaries, this period was marked by indisputable decline. Thus, as Ronald Syme describes in his groundbreaking twentieth-century study Sallust, there has been among modern historians a 'fashion of condemning and deploring the last epoch of the Roman Republic' (Syme, 2002, p. 16), echoing Sallust's belief of a 'such corrupt' (Sallust \& Ramsey, 2007, 14.1) society.

But the history of Catiline, as described in Cicero's Catilinarian orations and Sallust's Bellum Catilinae, complicates historians' desire for a single, "whole truth." In the simplest version of the story, Catiline, after losing the consulate election in 63 B.C. to Cicero, initiated a conspiracy. Cicero presented his four Catilinarian orations in response to the conspiracy and ultimately persuaded the senate to pass the senatus consultum ultimum in 62 B.C. Shortly after that, Catiline was beheaded during a battle led by M. Petreius. Although these events may seem relatively straightforward, interpreting the significance of Catiline's rebellion poses a challenge for historians. This task of historical interpretation is made even more difficult by the fact that Sallust's version of Catiline's story — one of the two major near-contemporary recordings - also takes into account the ambiguity of Catiline's character and circumstances. Sallust's approach to discuss Catiline, particularly his commitment to the old Roman virtue, is more nuanced than Cicero, and less ideological than modern historians have suggested.

In contrast to Sallust's intentionally nuanced and contradictory history, Cicero characterizes Catiline as unprecedentedly and 'thoroughly depraved' (Wilkins, 1994, p. 30). Cicero's passionate condemnation of Catiline makes sense in its historical context: Cicero presented the First Oration as Catiline's conspiracy was unfolding, and his account reflects the point-of-view of a consul hoping to save the Republic from collapse. Since Cicero's First Oration is one of only two major primary sources that characterize Cataline (the other being Sallust's Bellum Catilinae), it also makes sense that his viewpoint had an inestimable influence on historians through the early twentieth century. These historians joined Cicero in seeing Catiline's evil as an inherent flaw particular to his person.

Unlike Cicero, who 'establishes his own heroism' (Wilkins, 1994, p. 29) throughout the four Catilinarian orations, Sallust depicts his protagonist as a figure with strengths and weaknesses. As Wilkins notes, Sallust's characterization of Catiline 
'was composed some twenty years after the attempted revolution' (Wilkins, 1994, p. 29) and was probably intended to be more of a historical record than an accusation. Ronald Syme agrees that Sallust's account is more analytical and historical than an expression of personal bias. My analysis elaborates on this notion of a "more historical" account by examining Sallust's own understanding of history. Therefore, this paper will demonstrate how Sallust's nuanced writing of Catiline helps him discuss Rome and its problems more generally, further reflecting his role of being a historian, through 1) Catiline as the embodiment of Roman Republic's decline, 2) characters with ambivalent relationship among each other, by forming a polyphony through their speeches, and 3) the way he uses a form of didactic and moral implications to indicate the right action needed within Rome.

\section{Catiline: The Fall of Virtus}

Sallust's portrayal of Catiline is framed by his discussion of the fundamental dichotomy of mind (animus) and body (corpus). Bellum Catilinae opens its discussion on the differences between humans and animals by distinguishing 'physical force' (vine corporis, Sallust, 2010, 1.5) from 'mental excellence' (virtute animi, Sallust, 2010, 1.5). Sallust suggests that the virtuous human possesses a 'mind for control' (animi imperio, Sallust, 2010, 1.2) and 'body for servitude' (corporis servitio, Sallust, 2010, 1.2). With this standard established, Sallust seems to simply compliment Catiline when he mentions that Catiline was 'a man of great strength, both mental and physical' (Sallust \& Ramsey, 2007, 5.1). Sallust's praise of Catiline's physical attributes is, indeed, enthusiastic: he describes how Catiline's 'body could endure hunger, cold, sleep-deprivation' (Sallust \& Ramsey, 2007, 5.3), and he expresses admiration for the physical strength of his protagonist. Nevertheless, this admiration soon becomes ambivalent when Sallust describes how Catiline's strong body is not subject to an equally strong, well-governed mind. In contrast to his physical capability, Catiline's innate quality is 'wicked and perverse' (malo pravoque, Sallust, 2010, 5.1). The contradiction between Catiline's manliness and his vice points to his multifaceted nature.

Sallust also emphasizes the complexity of his protagonist by tying Catiline's individual strengths and weaknesses to a much longer history. Following his discussion of Catiline's body and mind, Sallust suggests the need to 'go further back in time and briefly discuss' (Sallust \& Ramsey, 2007, 5.9) Rome's past. This jump from Catiline's character to Rome's past and current condition encourages readers to draw parallels between the two. Just as Sallust depicts Catiline as a strong man who is corrupted by a weak mind, Sallust depicts Rome as a once-strong political body that has now been weakened. Sallust mentions 'how great a state they left us' (Sallust \& Ramsey, 2007, 5.9) to show the original strength of the state, which echoes Catiline's 'great strength, both mental and physical' at his birth (Sallust \& Ramsey, 2007, 5.1). Rome and Catiline also share the same fate. They fall from their state of greatness, one due to 'always longing for the extravagant' (Sallust \& Ramsey, 2007, 5.5) and the other due to 'ambition that worked the souls of men' (Sallust \& Ramsey, 2007, 11.1).

When Sallust describes how Catiline's corrupted nature 'was further encouraged by the corrupt moral character of the state' (Sallust \& Ramsey, 2007, 5.8), he suggests a direct relationship between his society's corrupted virtues and Catiline's fallen character. According to Sallust, the period when Catiline was born was marked by people's 'greed for money, then greed for power' (primo pecuniae, deinde imperi cupido, 2010, 10.3). Rather than viewing Catiline as unprecedentedly corrupted, Sallust seems to use Catiline as 'the platform to fully expand on the evil influence of luxuria in post-Sullan Rome' (Shaw, 1975, p. 189). Starting from 5.9, Sallust vividly depicts the degradation of the Republic by comparing the 'loveliest and best' (pulcherruma atque optuma, 2010, 5.9) of bygone eras with 'the worst and most depraved' (pessuma ac flagitiosissuma, 2010, 5.9) of the late Republic. In the harmonious, wealthy, and healthy Roman society of the past, Sallust describes that soldiers were 'generous with money' $(2007,7.6)$, 'fearless in war' $(9.3)$, and 'brought aid to their allies' (6.5) as a sign of compassion (beneficia). But, after the battle with Carthage, avarice and envy bewitched the Roman people. Contrary to demonstrating beneficia, Roman soldiers after Sulla 'left nothing for the defeated' (Cat. 11.7) in battles. The soldiers' cruelty, which arouses from 'ambition' (ambitio), is the opposite of the previous soldiers' 'fearless' (audacia, Sallust, 2010, 9.3). Likewise, Catiline's nature is corrupted 'because of two contradictory evils, extravagance and greed' (Sallust \& Ramsey, 2007, 5.8).

Sallust's emphasis on widespread corruption in the late Roman Republic is thus part of his effort to contextualize Catiline's complex nature rather than simply critique it. A final level of ambivalence appears when he mentions that Catiline had to suffer under his 'family's poverty' (Sallust \& Ramsey, 2007, 5.7), which required him to develop the ability to live without food. Sallust understands how this experience of poverty would strengthen Catiline's attention to his bodily needs and make him more likely to be 'seized and corrupted by ambition' (2007, 3.5), a tendency that Sallust admits falling prey to himself (3.4-5). Sallust's attention to his own human weaknesses and biases, however momentary, establishes an important point about his role as a historian. Since historians are also humans situated in complicated contexts, it would be impossible for them to represent a wholly "accurate" history. Thus, instead of aiming for this elusive "accuracy," Sallust points to his desire to tell a more nuanced story about the end of the Roman Republic.

\section{Speeches and Polyphony}

Intertwining the fate of Catiline with the downfall of Roman society presents the one nuance aspect of Sallust's writing. 
More importantly, the writer has a different way to express the same problem on a different level by introducing speeches of various characters. The four speeches in the book may seem isolated among each other when looking separately but possess deeper connection and meaning within the writing of a historian. This part will first analyze the two speeches by Catiline and then the debate between Cato and Caesar, to illustrate the discrepancies among speakers on the conspiracy; and I will then show how speakers form polyphony, to demonstrate Sallust's complicated understanding of Rome and historiography.

Sallust's inclusion of two speeches by Catiline - one before 64 B.C. that demonstrates his role as a political agent and one pre-battle that presents him as a committed military leader - is part of his effort to allow Catiline to be a dynamic and complicated character. These speeches are not entirely consistent with Sallust's characterization of Catiline earlier in his account. Batstone suggests that the morally depraved revolutionary criminal, who Sallust presents in the opening chapters of the Bellum Catiline, and the concerned and competent leader interested in reform and liberty, who appears in his speeches, are 'two sides of a complex individual' (Batstone, 2010, p. 228). Batstone, likewise, notes the existence of a contradiction. The contradiction becomes especially interesting, considering the lack of proof that these speeches existed on paper before Sallust was writing. It seems that Sallust creates these speeches using his own language, which means that he characterizes Catiline one way in his "historian" voice and characterizes him a different way when putting language in the mouth of his protagonist.

Adding to the complexity of Sallust's portrayal of Catiline, Catiline's ideals do not entirely contradict Sallust's own ideals. Catiline's opening emphasis on 'virtue and fidelity' (virtus fidesque, Sallust, 2010, 20.2) in the first speech links the past Roman virtues that Sallust praised with Catiline. Catiline describes a loss of libertas - a concern shared by Sallust-and criticizes 'sloth and empty intelligence' (Batstone, 2010, p. 232) as Sallust would. Although Sallust defends the old Roman Republic and Catiline hopes to incite rebellion, Sallust and Catiline have similar concerns about the uncertainty plaguing Rome. When Catiline refers to his followers as amicitia, he also harkens back to an older, more stable period. Batstone describes how this use of amicitia 'recalls the concordia that secures the commonwealth (6.2) and the amicitia that builds empire (6.5-6)' (2010, p. 233).

The parallels between Catiline's and Sallust's hopes for Rome continue in Catiline's series of rhetorical questions. Catiline asks: 'How long will you endure, most brave men? Is it not better to die virtuously than to lose a wretched life disgracefully?' (Sallust \& Ramsey, 2007, 20.9). In this “imagined” speech that Sallust writes for Catiline, Sallust chooses to have Catiline echo Cicero's style in the opening of First Catilinarian. Instead of making Cicero the hero and Catiline the enemy of the state, Sallust turns Catiline into a rhetorical equal to Cicero in defending his hope for libertas. Sallust's choice to depict Catiline as a leader who would care about dying "virtuously" — of fighting for a noble cause — also aligns Catiline with his notion of virtus. Catiline ends his first speech with a 'diminuendo, offering himself as a general or a soldier' (Batstone, 2010, p. 234), which suggests a body that is in service to a greater cause. Just as Sallust initially praised the "mind in control" and "body for servitude," Catiline now seems to prioritize something greater than his individual body. Rather than distancing Catiline from older Roman virtues, the speech exemplifies Sallust's values. Again, in his second speech, Catiline asks his followers to fight with him in order to achieve gloriam, libertatem, and most importantly patriam (Sallust, 2010, 58.8). The word patriam, meaning fatherland, reflects Catiline's strong fidelity to his own country, the fides that Sallust emphasizes when discussing the virtue of Romans.

Despite the parallels between Catiline's and Sallust's virtue, Sallust also criticizes Catiline's perception that overcoming oppression requires 'reckless courage' $(2007,58.15)$. Thus, although Catiline and Sallust point out some of the same underlying issues in the Roman Republic, they disagree on whether audacia is necessary to achieve libertas. In fact, Sallust himself seems to have mixed feelings about audacia and whether it represents recklessness or courage. For instance, at the end of his account, Sallust praises the 'daring and mental toughness of Catiline's army' (audacia quantaque animi vis fuisset in exercitu Catilinae, 2010, 61.1). At the same time, he believes audacia was an indication of soldiers' recklessness and represented the downfall of the Republic. Therefore, despite using audacia to praise the soldiers in the past and in Catiline's army who 'were fearless in war' (Sallust \& Ramsey, 2007, 9.3), Sallust seems to imply that when deeds or avarice were involved in boldness of soldiers, audacia may represent a negative innate quality. Far from portraying Catiline as either good or bad, Sallust depicts his character as possessing a quality that can sometimes be virtuous and other times be dangerous to the good of the Republic.

Sallust's representation of Caesar and Cato's different opinions of Catiline also contributes to his characterization of Catiline as a multidimensional figure. In his speech, Caesar becomes Sallust's mouthpiece in defending the "mind for control." He advocates a well-reasoned evaluation of Catiline's virtues and faults because he emphasizes how "the mind cannot easily see the truth ... when passion takes over' (Sallust \& Ramsey, 2007, 51.2-3). He praises his ancestors who would 'consider anger not as important as reputation' (2007, 51.7), suggesting that their ability to control their anger allowed them to preserve their reputation and achieve more lasting gloria. Emphasizing Catiline's admirable commitment to libertas, Caesar depicts Catiline not as someone who 'stirred up the revolutionary spirit' (Sallust \& Ramsey, 2007, 51.10), but as someone trying to uphold a long-standing Roman value. In fact, Caesar asks the senators, "who did not 
praise Sulla?' (Sallust \& Ramsey, 2007, 51.32), which reminds them that Catiline has precedence for his actions. Because of people's praise for Sulla and the already-present revolutionary spirit in the society, Caesar suggests that Catiline's case should be considered rationally.

In contrast, Cato appeals to the senators' emotions by depicting Catiline's rebellion as an unprecedented violation of justice. He warns that 'if [the senators] do not act to prevent this crime, when it does occur, justice will be lost' (Sallust \& Ramsey, 2007, 52.3). He does not refer to the virtues of the conscript fathers because, as he explicitly says, he is not interested in discerning 'a moral compass' (Sallust \& Ramsey, 2007, 52.10). Instead, he claims that dealing with Catiline's conspiracy is an immediate problem that requires an urgent solution. Whereas Caesar suggests that the senators' greed and laziness make them more likely to act rashly and without thought, Cato suggests that the senators' addiction to wealth and pleasure makes them too soft and too hesitant to act. He thus advocates severitas due to the ineffectiveness of 'compassion and mercy' (Sallust \& Ramsey, 2007, 52.11) and the unprecedentedness of Catiline's situation. Throughout the speech, he treats Catiline as national enemy and even compares him to the Gauls, who are 'angry and hostile' (irati infestique sunt, Sallust, 2010, 52.29). Cato's abundant use of rhetorical questions indicates his use of pathos to persuade senators to adopt a severe policy.

In Bellum Catiline, Sallust aligns himself more closely with Caesar's approach than Cato's. He states that his purpose is 'to write out the history of the Roman people' $(2007,4.2)$, and he emphasizes his ability to lay out the history in an "objective" way because he is 'free from political hopes, fears, and partisanship' (2007, 4.2). Similar to Caesar's insistence on a mind cleared of anger and momentary passions, Sallust suggests that a good historian's mind needs to be cleared of individual biases. Thus, Sallust includes the four speeches by Catiline, Caesar, and Cato not only to characterize these historical figures, but also to depict these figures as historians, interpreting the events of history for their audiences. Caesar, Cato, and even Catiline himself offer their analyses of Catiline's rebellion and, more importantly, the decline of Rome. More than just orators or senators, they are historians within Sallust's history and the shapers of the history that Sallust narrates. Their voices seem to form dialogues among each other, creating polyphony.

Although Sallust's deliberate use of polyphony allows Catiline's, Caesar's, and Cato's voices to be heard in his account, he also uses his authorial voice to subtly criticize Cato and commend Caesar. When Caesar opens his speech by reminding listeners that any participant in debate 'ought to be free from hatred, enmity, anger, and pity' (Sallust \& Ramsey, 2007, 51.1), he seems to anticipate Cato's emotional speech that argues for severe punishment against Catiline. Sallust uses Caesar to present his argument in defense of the mind's rightful dominance, and Cato, before he even begins, is the counterexample to Caesar's freedom from hatred, enmity, anger, and pity. Sallust also uses Catiline's second speech to refute Cato's sense that Catiline is nothing but a villain who deserves the worst of punishments; in this second speech, Catiline emphasizes fidelity to patriam, which complicates his so-called villainy. Cato's disregard for a moral compass makes him an advocate for punishment purely for utilitarian reasons. Whereas Caesar (and Sallust) believe in humans' ability to control their fears and anger, Cato can only imagine a 'mob using violence to set them free' (Sallust \& Ramsey, 2007, 52.14). Using the Lacedaemonian's conquer of Athens as an example, Caesar proves that humans need not be governed by these irrational passions.

Further, Caesar argues that, to understand Catiline, audiences must need to re-evaluate past revolts, especially the Sullan example. By asking the senators 'who did not praise Sulla?' (Sallust \& Ramsey, 2007, 51.32), Caesar proposes that the senators lacked beneficia (which they beheld years ago facing Sulla) when they were making decision about Catiline's fate. While also emphasizing the influence of Sulla's revolt, Cato indicates how the Sullan example took away the senators' severity, which in fact turned them to possess more beneficia. Here, Sallustian analysis then plays a role as a bridge between Caesar and Cato. Sallust suggests that the Republic '[has] been transformed by the Sullan moral revolution' (Feldherr, 2016, p. 105), as Andrew Feldherr believes. With no indicator of which effect the transformation had on the senators, Sallust may present Caesar and Cato as two opposite voices to show the complexity of the post-Sullan environment.

Just as Sallust aligns his own worldview and rhetorical approach with Caesar's, he aligns Cato's emotional rhetoric with Catiline's. The dialogues among these historic "writers" even share similarities in structures when Sallust responds to Cato's rhetorical questions by using the same Axiosis in three questions in Catiline's first speech (Sallust \& Ramsey, 2007, $20.9,20.11,20.13$ ). Both Cato and Catiline suggest that their audiences need to be awaken, and, by using similar styles of rhetorical questions, Sallust demonstrates the same emotional spirit possessed by the two characters. Their passionate phrases contrast with Caesar's impassionate language. Different from Caesar's emphasis on a well-controlled mind, Cato and Catiline advocate extreme measures for solving the underlying problem of society.

\section{Historian and His Further Implication}

Sallust believes that recording history is one way to be a worthy human being, but his methods differ from Cicero's. Sallust believes that a good historian needs to go beyond the "accuracy" advocated by Cicero and recognize that all historical issues have multiple complicated angles. According to Sallust, making simplistic or straightforward judgments about a complex character like Catiline does not qualify as writing accurate history. Instead, he tries to treat his subjects 
with the same rationality and balance that Caesar describes. After all, he knows that a person's lasting reputation depends on historical accounts of their deeds. He explains, 'First of all, deeds must find an equivalence in words' $(2007,3.2)$. Recognizing that Catiline's "deeds" will be remembered based on his own words, Sallust strives to provide a well-rounded account. He describes Catiline's evil nature, but also explains factors that contributed to that nature. $\mathrm{He}$ describes the "old" Roman virtues, but also represents Catiline as a figure who embodied those supposedly extinct virtues. He makes Catiline a revolutionary criminal, but also appreciates his loyalty to his ideals. More than anything, he allows Catiline, Caesar, and Cato to present their differing opinions in their own voices, even as he adds his subtle commentary and critique to those voices.

Nevertheless, I believe Sallust is not simply giving a more complicated analysis of Catiline. If he is indeed doing so, it would be hard to differentiate him from other "historians" who give the speeches in his book. On the contrary, there may be something more that rests on his shoulder as a historian: to provide a "wake-up call" to his audiences that it was necessary to behold virtus to save the Republics. In fact, when Sallust incorporates his own voice into Catiline's speeches, we could see how Catiline (as well as Sallust) was warning his audiences 'so, why don't [we] wake up' (Sallust \& Ramsey, 2007, 20.14). For Catiline, he may be desiring his followers to fight with him, but when we understand his speech as part of Sallust's voice, we could see Sallust's evocation to his readers to wake up to solve the true problems underlying in the Republic.

At the end of his account, he describes how the senate's victorious army 'moved in different ways to joy, sorrow, grief, and happiness' (Sallust \& Ramsey, 2007, 61.9). The chiasmus structurally (laetia and maeror; luctus and gaudia) captures the complicated emotions in civil war, and most importantly, the uncertainty of people during that period. Sallust sees it clear. He understands how after the Gracchus brothers, Sulla, the Social War, and Catiline, revolutions were becoming a norm in the society. When Andrew Feldherr indicates that 'Caesar should be read as a historiographic Cassandra' (2016, p. 104), Sallust seems to fit this name better. He is different from Caesar and Cato since he does not possess the power as a senator; at the same time, he is different from Catiline, a failing revolutionary leader who would be forgotten by time. Rather, Sallust beholds the true ideology of humankind with his body and mind analysis but perceives the inevitability of deed entering one's mind and taking away the innate and original quality as mentioned in his preface. His work, thus, goes further beyond history recording and proposes the widespread of the revolutionary spirit within the Roman Republic.

Just as Wilkins comments here, 'Roman fights Roman, neither side is victorious, neither defeated, while both are diminished' (1994, p. 138). This is the big picture of the late Roman Republic that Sallust is presenting. When years later Caesar successfully declared dictatorship, maybe the historian taking account of the leader's early debate has already foreseen it arriving and people may have finally realized the complicated nature of Catiline's case.

\section{References}

Batstone, W. W. (1988). The antithesis of virtue: Sallust's "synkrisis" and the crisis of the late republic. Classical Antiquity, 7(1), 1-29. Retrieved from JSTOR database. https://doi.org/10.2307/25010876

Batstone, W. W. (2010). Catiline's speeches. Form and Function in Roman Oratory, 227-246.

Cicero, M. T. (2010). Catilinarians (3rd ed.) (A. R. Dyck, Ed.). Cambridge: Cambridge UP.

Cicero, M. T. (n.d.). De oratore book 2 (J. S. Watson, Trans., C. Chinn, Ed.). Retrieved from http://pages.pomona.edu/ cmc24747/sources/cic_web/de_or_2.htm

Coffee, N. (2017). Sallust and the decline of reciprocity. Gift and Gain: How Money Transformed Ancient Rome. Retrieved from Oxford Scholarship Online database. https://doi.org/10.1093/acprof:oso/9780190496432.001.0001

Feldherr, A. (2016). Time and narrative in ancient historiography (Vol. 6) (J. Grethlein, Ed.). Cambridge Univ Press.

Sallust, \& Ramsey, J. T. (2007). Sallust's bellum catilinae (2nd ed.). Oxford: Oxford UP.

Sallust. (2010). Catiline's conspiracy: The jugurthine war; histories (W. W. Batstone, Trans.). Oxford: Oxford UP.

Shaw, B. D. (1975). Debt in sallust. Latomus, 34(1), 187-196. Retrieved from JSTOR database.

Syme, R. (2002). Sallust. Berkeley: Univ. of California Press.

Wilkins, A. T. (1994). Villain or hero: Sallust's portrayal of catiline. New York: Lang.

\section{Copyrights}

Copyright for this article is retained by the author(s), with first publication rights granted to the journal.

This is an open-access article distributed under the terms and conditions of the Creative Commons Attribution license which permits unrestricted use, distribution, and reproduction in any medium, provided the original work is properly cited. 